\title{
The Relationship of Family Support with Elderly Independence in Fulfillment of Daily Living Activity in the Middle of the COVID-19 Outbreak in Pangkep District
}

\author{
Isymiarni Syarif \\ Department of Health Sciences, University of Islam Makassar, Makassar, Indonesia
}

\begin{abstract}
Background: The existence of the elderly (elderly) is characterized by an increasing life expectancy from year to year. An increase in the number of elderly will cause various health problems including those that cause a decrease in the productivity of the elderly. The decline in productivity in the elderly due to decreased function, so that the elderly can lead to decreased independence in carrying out daily activities without exception in the midst of an outbreak of Covid 19. The purpose of this study is to identify the picture of the level of independence in fulfilling the daily activities of living in the midst of an outbreak of covid-19.

Methods: This study design is analytic with cross sectional approach. The total sample was 109 elderly people aged 60 years and over. The instrument uses a questionnaire and the measurement instrument uses the Barthel index. The data analysis technique used Spearman Rho.

Results: The results showed that 96 respondents (79\%) had high family support, 12 (19.4\%) received moderate family support, and 1 respondent $(1.6 \%)$ had low family support. 13 respondents $(21 \%)$ were in the moderately dependent category and 96 respondents (79\%) were in the independent/independent category.

Conclusion: There is a positive and significant relationship between family support and the independence of the elderly in fulfilling daily activities in the midst of the Covid 19 outbreak in Pangkep Regency. Increasing family support for the elderly is very necessary for the independence of the elderly. Health centers are advised to provide intensive counseling to
\end{abstract}

families so that they provide greater support to the elderly.

Keywords: elderly independence, daily activities, family support, Covid 19

\section{INTRODUCTION}

Infection caused by the novel coronavirus (COVID-19) was first detected in December 2019 in Wuhan in Hubei Province, China. The World Health Organization (WHO) declared the outbreak a Public Health Emergency of International Concern in January 2020. After SARS and MERS, COVID-19 has become the third pandemic caused by the coronavirus to cause worldwide panic. Considering it as a disease with a high risk of transmission, the WHO has issued the necessary guidelines to deal with the transmission of Covid 19. Because COVID-19 is a new virus, there is no population that has antibodies to it worldwide. Therefore, everyone has the opportunity to get infected, including the elderly (elderly).

This is in line with a case study from Hubei Province, China ${ }^{[1]}$ reporting that $87 \%$ of cases were aged $30-79$ years and $3 \%$ of cases were aged 80 years, with an overall case fatality rate (CFR) of $2.3 \%$ with cases aged 70-79 years CFR 8.0\%, cases aged 80 years CFR $14.8 \%$ and the number of female cases was $41.9 \%$. This suggests that the elderly are particularly at risk of exposure to COVID-19 and that older men are more susceptible to SARS-CoV-2 compared to 
older women, and this virus is more likely to affect elderly men with underlying chronic diseases (e.g. diabetes, hypertension, cardiovascular disease, etc.). heart, etc.).

The elderly have an increased risk of contracting COVID-19 infection, because the body loses function with age, poor diet, lack of exercise, and loneliness, making the elderly also fall into the Covid-19 vulnerable group. The elderly tend to be vulnerable to adverse health effects because they are constantly at home. The situation of maintaining distance and self-isolation at home becomes more difficult for the elderly, especially for the elderly who are victims of depression and other mental health problems. This is in line with what Rc jiloha (2020) stated that the elderly (elderly), especially in isolation and those with cognitive decline or dementia, can become more anxious, angry, stressed, restless and withdrawn during an outbreak or while in quarantine. . These people need the emotional support of informal networks (family) and health professionals ${ }^{[2]}$.

Family support is highly expected for the elderly during this COVID-19 pandemic/epidemic. Seniors must stay at home and must avoid public places, wear masks and maintain a distance of at least one meter from other people when outdoors. Independent quarantine / self-isolation must be followed by the elderly to minimize the spread of covid 19 infection, this may cause stress in the elderly, There may be feelings of ostracism, abandonment and neglect in the elderly when at home, causing psychological problems in the elderly.

Families are expected to be present at home and supervise and monitor the elderly in carrying out daily activities. The independence of the elderly in carrying out daily activities requires family support, so that the elderly psychologically still feel cared for, loved, considered important in their presence in the family. This is in line with Gloria HY Chan's research (2019) in Hemavathi Shanmugam (2020), that a person's psychological needs are very important and become a determinant of being able to carry out activities and other life substances ${ }^{[3]}$.

In addition to psychological problems, the elderly also experience a decline in the functions of their limbs which can cause problems or interfere with daily activities. For example, slow movement, less fast action, reduced body resistance, reduced reproductive health system and others (BKKBN, 2012). These changes generally lead to a decline in physical and psychological health which will ultimately affect the economy and social life of the elderly. So in general it will affect the activity of daily living ${ }^{[4]}$.

Physical changes in the elderly will affect the independence of the elderly in carrying out daily activities in any situation, including in the midst of the covid 19 outbreak. Independence is the freedom to act, not depending on others, not being influenced by others and free to regulate oneself or one's activities, both individuals and groups of various health or disease. Independent is also said to take care of oneself or take care of oneself and can carry out activities of daily life ${ }^{[5]}$.

Problems that are so complex in the midst of the COVID-19 outbreak require immediate action, so family support is needed, for example through adequate daily care such as personal hygiene care such as dental and oral hygiene, skin and body hygiene, and hair hygiene. The family support is intended so that the elderly are able to be independent or get minimal assistance and make the elderly independent [6].

Optimal family support encourages the health of the elderly to improve, besides that the daily activities of the elderly become regular and not excessive even at home in the midst of the covid 19 outbreak. Part of social support is love and affection which must be seen separately as part of care and attention in the effective functioning of the family ${ }^{[5]}$. The general condition of the elderly living with their families shows that the family plays an 
important role in the lives of the elderly, especially if the elderly experience various physical and mental function disorders. According to the results of research conducted by Samalagi; Rumende; Rondonuwu (2014) ${ }^{[7]}$, stated that family support is very important in a person's independence in old age. Research conducted by Chuluq; Fathoni; and Hidayati (2012) also stated that the better the family support, the better the independence of the elderly in fulfilling the Activity Daily Living (ADL). However, it is unfortunate that there has been no previous research and literature related to family support with the independence of the elderly in meeting their daily needs (Activity Daily Living) in the midst of the covid 19 outbreak ${ }^{[8]}$.

Based on the description of the theory and phenomena above, the author is interested in researching "The relationship between family support and independence. The elderly in fulfilling daily activities (Activity Daily Living) in the midst of the Covid 19 outbreak in Pangkep Regency"

\section{RESEARCH METHODS}

Design of this study was analytic with approach cross sectional. The total sample was 109 elderly people aged 60 years and over. The instrument uses a questionnaire and the measurement instrument uses the Barthel index. Data analysis technique using Spearman Rho. The sampling technique used is Simple Random Sampling. Simple Random Sampling is taking sample members from the population which is done randomly without regard to the strata that exist in the population ${ }^{[9]}$.

\section{RESULTS}

Table 1 shows that most of the elderly in Pangkep Regency received high family support in the midst of the COVID19 outbreak, namely 96 respondents (79\%).

Table 1. Distribution of Family Support Family

\begin{tabular}{|l|l|l|}
\hline Support & n & \% \\
\hline Low & 1 & 1.6 \\
\hline Medium & 12 & 19.4 \\
\hline High & 96 & 79.0 \\
\hline Total & 109 & 100 \\
\hline
\end{tabular}

Table 2. shows that the independence of the elderly in fulfilling daily activities in the midst of the COVID19 outbreak in Pangkep Regency is mostly in the independent category, as many as 96 respondents $(79 \%)$.

Table 2. Distribution of the independence of the elderly

\begin{tabular}{|l|l|l|}
\hline Self-reliance & F & Percentage \\
\hline Dependent total & 0 & 0 \\
\hline Dependent Heavy & 0 & 0 \\
\hline Dependent Medium & \multicolumn{1}{|c|}{13} & $21 \%$ \\
\hline Dependent Mild & 0 & 0 \\
\hline Independent/ independent & \multicolumn{1}{|c|}{96} & $79 \%$ \\
\hline Total & 109 & $100 \%$ \\
\hline
\end{tabular}

In table 3 shows the results of thestatistical test Spearman Rho, the value of $p=0.000$, and $r=0.998$. Because the $p$ value $(0.000)<=0.05$, then $\mathrm{H} 0$ is rejected and $\mathrm{H} 1$ is accepted, meaning that there is a relationship between family support and the independence of the elderly in fulfilling daily activities in the midst of the covid 19 outbreak. The value of $r=0.998$ indicates a very strong correlation and the direction of the correlation positive relationship between family support and the independence of the elderly in fulfilling daily activities in the midst of the covid 19 outbreak

Table 3. Spearman test to determine the relationship between family support and the independence of the elderly in fulfilling daily activities in the midst of the covid 19 outbreak wabah

\begin{tabular}{|l|l|l|l|l|}
\hline \multicolumn{3}{|c|}{ Spearman's rho } & Family support & Fulfillment of daily activities \\
\hline \multirow{3}{*}{ Family support } & Correlation Coefficient & 1,000 & $.998^{* *}$ \\
\cline { 3 - 5 } & Sig. (2-tailed) &. & .000 \\
\cline { 2 - 5 } & $\mathrm{N}$ & 109 & 109 \\
\cline { 2 - 5 } & Fulfillment of daily activities & Correlation Coefficient & $.998^{* *}$ & 1,000 \\
\cline { 3 - 5 } & & Sig. (2-tailed) & .000 &. \\
\cline { 3 - 5 } & & $\mathrm{n}$ & 109 & 109 \\
\hline
\end{tabular}

\section{DISCUSSION}

Family support is highly expected for the elderly during this COVID-19 pandemic/epidemic. Seniors must stay at home and must avoid public places, wear masks and maintain a distance of at least 
one meter from other people when outdoors. Independent quarantine / self-isolation must be followed by the elderly to minimize the spread of covid 19 infection, this may cause stress in the elderly, There may be feelings of ostracism, abandonment and neglect in the elderly when at home, causing psychological problems in the elderly.

Families are expected to be present at home and supervise and monitor the elderly in carrying out daily activities. The independence of the elderly in carrying out daily activities requires family support, so that the elderly psychologically still feel cared for, loved, considered important in their presence in the family. This is in line with Gloria HY Chan's research (2019) in Hemavathi Shanmugam (2020), that a person's psychological needs are very important and become a determinant of being able to carry out activities and other life substances ${ }^{[3]}$.

The emotional support provided is in the form of caring for family members for the independence of the elderly in daily activities, such as paying attention by creating a safe and comfortable home environment for carrying out activities, listening to the elderly's outpourings and giving affection to the elderly. The elderly not only need physical support but also the emotional connection between family members will greatly support the elderly in maintaining their independence. The better the family's emotional support for the elderly, the more independent the elderly will be in fulfilling daily activities.

Providing emotional support to an elderly person will make them better, regain their confidence, feel owned and loved during times of stress so that they can improve the quality of humanity, personality stability and behavior and self-esteem of family members. In personality theory according to Ericson (1902-1994) it is stated that the elderly (who are over 60 years old) feel that their lives are close to the end of life and at this time the affection from the closest family is a pleasure in itself. This shows that family care will benefit not only physically but also psychologically for the elderly ${ }^{[10]}$.

In addition to psychological problems, the elderly also experience a decline in the functions of their limbs which can cause problems or interfere with daily activities. For example, slow movement, less fast action, reduced body resistance, reduced reproductive health system and others (BKKBN, 2012). These changes generally lead to a decline in physical and psychological health which will ultimately affect the economy and social life of the elderly. So in general it will affect the activity of daily living ${ }^{[4]}$.

Physical changes in the elderly will affect the independence of the elderly in carrying out daily activities in any situation, including in the midst of the covid 19 outbreak. Independence is the freedom to act, not depending on others, not being influenced by others and free to regulate oneself or one's activities, both individuals and groups of various health or disease. Independent is also said to take care of oneself or take care of oneself and can carry out activities of daily life ${ }^{[5]}$.

The results of thecorrelation test Spearman Rank show that there is a correlation between the two variables because the significance value of $p=0.000$ $<0.05$. Based on the value of the correlation coefficient $(r=0.998)$, it shows a strong relationship (closer to 1 ) with a positive correlation direction which means the better the family support, the better the independence in fulfilling daily activities amidst the covid 19 outbreak which means that between family support and independence in fulfilling daily activities in the midst of the covid 19 outbreak with a value of 0.998 which means the level of the relationship is strong.

Based on the results of the study, it was also found that the elderly who received family support in the high category were able to fulfill Activity of Daily Living independently with a total of 96 people (79\%). In the elderly, it can be seen that family support has an effect on 
independence in fulfilling Activity of Daily Living because in the elderly who get good family support, the number of elderly who are independent in fulfilling Activity of Daily Living is greater than the elderly who are partially dependent on fulfilling Activity of Daily Living.

The family has a function as a supporter of other family members who are always ready to provide assistance when needed. Family support is a process that occurs throughout life. The results of this study are in accordance with research conducted by Putri and Permata, which showed that from 84 elderly people studied, $61(72.6 \%)$ elderly people who had healthy family functions also had poor quality of life as many as 18 people (21.4\%). The elderly who have unhealthy or sick family functions and have a good quality of life are 3 people (3.6\%).

Friedman (2003) states that family support is the best preventive intervention strategy in helping family members access social support that has not been explored for an assistance strategy that aims to increase strong family support. Family support refers to support that is seen by family members as accessible to the family, family members' view that supportive people are always ready to provide help and assistance if needed ${ }^{[11]}$. Family support as a process of relationships between families and their social environment, the four dimensions of family support interactions are reproduction (reciprocity), feedback (quality and quality of communication) and emotional involvement (depth of intimacy and trust) in social relationships. Both the nuclear family and extended family function as a support system for family members and are active actors in modifying and adapting the personal relationship community to achieve a changing state ${ }^{[11]}$. The family is part of the elderly, so the family is still expected to be support system the mainfor a prosperous elderly life. The better the support provided by the family, the more independent the elderly are in fulfilling their daily activities.

\section{CONCLUSION}

Family support for the elderly is mostly 49 respondents (79\%) with high criteria. The independence of the elderly towards the fulfillment of daily activities, most of the 49 respondents (79\%) were in the category independent. There is a positive and significant relationship between family support and the independence of the elderly in fulfilling activities. So it is recommended for families to provide time to serve and listen to the sick elderly so that it is hoped that the elderly can be more comfortable and make the elderly's health well controlled and can improve their health status. It is hoped that the puskesmas will continue to carry out home visits for the elderly who are unable to maintain their health.

\section{Acknowledgement: None}

\section{Conflict of Interest: None}

\section{Source of Funding: None}

\section{Ethical Approval: Approved}

\section{REFERENCES}

1. Lisheng Wang, Yiru Wang, Dawei Ye, Qingquan Liu. 2020. Review of the 2019 novel coronavirus (SARS-CoV-2) based on current evidence. Elsevier B.V. and International Society of Chemotherapy. International Journal of Antimicrobial Agents,

https://doi.org/10.1016/j.ijantimicag.2020.1 05948

2. RC Jiloha. 2020. COVID-19 and Mental Health. Special Issue on SARS-CoV-2 (COVID-19) - Epidemiology International Volume 5, Issue 1 - 2020, Pg. No. 7-9

3. Hemavathi Shanmugam, Johan Ariff Juhari, Pritiss Nair,Chow Soon Ken, Ng Chong Guan. 2020. Impacts of COVID-19 Pandemic on Mental Health in Malaysia: A Single Thread of Hope. Department of Psychological Medicine, Faculty of Medicine,University of Malaya, Kuala Lumpur, Malaysia. BRIEF COMMUNICATION. MJP Online Early,01-05-20. 
Isymiarni Syarif. The relationship of family support with elderly independence in fulfillment of daily living activity in the middle of the COVID-19 outbreak in Pangkep district.

4. Fatma. (2010). Gizi Usia Lanjut. Jakarta:

5. Stanley, M., \& Beare, P. G. 2006. Buku Ajar Keperawatan Gerontik. Jakarta: EGC.

6. Nugroho, Wahjudi. 2014. Keperawatan Gerontik dan Geriatrik. Jakarta: EGC

7. Samalagi, Jein Christine, Rumende, Rooije R.H., Rondonuwu, Peekie. 2014. Hubungan Dukungan Keluarga dengan Kemandirian Lansia Dalam Pemenuhan Aktivitas Seharihari di Desa Kakara B Kecamatan Tobelo Kaupaten Halmahera Utara. Buletin Sariputra. Fakultas Keperawatan Universitas Sariputra Indonesia Tomohon. Diakses tanggal 23 Januari 2017

8. Chuluq Ar, Chusnul, Fathoni, M., Hidayati, Zakiyah. 2012. Hubungan Dukungan Keluarga Dengan Kemandirian Dalam Pemenuhan Activity Daily Living (ADL) Pada Lansia Wanita di Kampung Karang Werdha Puntodewo 1 Kelurahan Bunulrejo Malang. Jurnal. Fakultas Keperawatan
9. Sugiyono. 2013. Metode Penelitian Kuantitatif Kualitatif dan R \& D. Bandung : Alfabeta

10. Hardywinoto. 2005. Panduan Gerontologi: Tinjauan Dari Berbagai Aspek. Cetakan kedua. Jakarta: PT. Gramedia Pustaka Utama.

11. Friedman, Marilyn M. 2010. Buku Ajar Keperawatan Keluarga : Riset, Teori dan Praktek. Jakarta : EGC

How to cite this article: Syarif I. The relationship of family support with elderly independence in fulfillment of daily living activity in the middle of the COVID-19 outbreak in Pangkep district. International Journal of Science \& Healthcare Research. 2021; 6(3): 35-40. DOI: https://doi.org/10. 52403/ijshr.20210707 